\title{
Evaluating the demand for meat in South Africa: An econometric estimation of short term demand elasticities
}

\author{
Marion Delport*, Marlene Louw, Tracy Davids, Hester Vermeulen and Ferdi Meyer
}

Bureau for Food and Agricultural Policy, University of Pretoria, South Africa

*Correspondence to: Marion Delport, mariondelport21@gmail.com

\begin{abstract}
The study aims to improve understanding of meat demand in South Africa through the estimation of a Linear Approximation of an Almost Ideal Demand System (LA/AIDS) for the South African meat complex which includes beef, mutton, pork and poultry. As the most widely consumed animal protein, a special focus is placed on poultry, which is disaggregated into two separate product groups, namely IQF portions and other poultry products, providing an improved understanding of demand preferences among different poultry cuts. In light of the changes that have occurred in both global agricultural markets and the South African consumer environment over the past decade, the model is estimated based on monthly data from January 2008 to September 2014, yielding short run elasticities. Expenditure elasticity estimates for IQF portions, other poultry products, pork, mutton and beef were 1.17, 1.24, $0.44,1.07$ and 0.8 respectively and the compensated own-price elasticities were estimated as $-0.61,-0.43,-0.72,-0.96$ and -0.11 for IQF portions, other poultry products, pork, mutton and beef, respectively. Most of the estimated elasticities conformed to a priori expectations, with the exception of poultry expenditure elasticities, which were higher than expected and in line with luxury goods rather than normal goods as the most affordable source of protein. Within the lower income consumer groups, where poultry dominates meat consumption, it was argued that meat in itself is a luxury good, reflected in the elasticities of poultry as the most affordable entry point into the meat market.
\end{abstract}

Keywords:

Demand elasticities; meat; LA/AIDS; South Africa 


\section{Introduction}

As Goddard and Glance (1989) pointed out, there is no "correct" or "final" demand relationship for a specific commodity market and thus the monitoring of a specific commodity market is an on-going process. Without demand, production and marketing are futile exercises. Following rapid expansion in global meat consumption over the past decade, the 2015 edition of the OECD-FAO agricultural outlook expects global meat consumption to reach $35.4 \mathrm{~kg}$ per capita in retail weight equivalent (r.w.e.) by 2024 , an increase of $1.5 \mathrm{~kg}$ r.w.e. from 2014 levels. Much of the increase in meat consumption over the past decade has been attributed to the rise of the middle class in developing countries, a phenomenon which has been well documented globally, particularly within the BRICS region (Nieftagodien and Van der Berg, 2007; Ravillion, 2010; Ncube, Lufumpa and Kayizzi-Mugerwa, 2011; Tschirley, Reardon, Dolislager \& Snyder, 2015; Visagie, 2015). This growing middle class is typically associated with changes in food consumption preferences as consumers move from a traditional, starch based diet to a more protein rich alternative. However, Tschirley et al. (2015) note that detailed analyses of the food consumption behaviour of the middle class remain lacking.

The increase in meat consumption at the expense of traditional starches in developing countries has become known as the Livestock Revolution. Seale, Regmi and Berstein (2003) indicate that a higher share of disposable income dedicated to food in lower income countries has fuelled the Livestock Revolution in these lower income regions compared to more developed, higher income economies. Furthermore, population growth in the more developed regions tends to be slower and in many of these regions, meat consumption on a per capita basis has reached saturated levels. Whilst food budgets grow slower for higher income consumers, global food consumption patterns are rapidly changing with growing demand for quality, variety and convenience.

From 1970 to 2003, total South African meat consumption remained relatively constant, at about $41 \mathrm{~kg}$ per capita per year, despite an increase in real per capita income (Taljaard, Jooste and Asfaha, 2006). While from 2003 to 2015, the total South African meat consumption increased by $54.4 \%$ to $66.83 \mathrm{~kg}$ per capita (Abstract of Agricultural Statistics, 2016); during the same period, disposable income per capita increased at an average annual rate of $3.2 \%$ up until 2009 and at a slower rate of $0.8 \%$ per annum after 2009. Furthermore, the composition of meat consumption changed: chicken / white meat consumption tripled from $7.7 \mathrm{~kg}$ per capita per year in 1970 to $21.2 \mathrm{~kg}$ per capita per year in 2002 , at the cost of red meat consumption (beef and sheep) while pork consumption remained relatively constant at $3 \mathrm{~kg}$ per capita per year. From 2002 to 2015, similar meat consumption composition changes were observed: chicken / white meat consumption increased further to $39.6 \mathrm{~kg}$ per capita per year (contributing 59\% of the total South African meat consumption in 2015) while the proportion of beef and veal in the meat consumption composition decreased to $29 \%$ in 2015 . Sheep and goat consumption increased from $2.8 \mathrm{~kg}$ per capita per year in 2002 to $4.7 \mathrm{~kg}$ per capita per year in 2015 and pork consumption remained relatively stable at $3.6 \mathrm{~kg}$ per capita per year in 2015 (Abstract of Agricultural Statistics, 2016). Taljaard et al. (2006) quantified the effect of 
non-economic factors on the demand for meat by applying Ordinary Least Squares (OLS) and the Johansen cointegration approach. Even though no definite conclusion is drawn in terms of reasons for changes in meat consumption, the results by Taljaard et al. (2006) indicate that a higher proportion of changes in most meat consumption categories is explained by non-economic factors (with the exclusion of white meat consumption).

Since the last meat demand elasticity estimations in South Africa by Taljaard (2003), much has changed in terms of consumption patterns in South Africa as well as the price environment internationally and domestically. It is therefore warranted to revisit the domestic meat market, in order to quantify changes in consumption patterns in recent years. Updated meat expenditure- and substitution elasticities are invaluable market intelligence that could facilitate policy analysis on, inter alia, the effect of rising food prices on consumers. Some of the main issues that could have had an impact on meat demand over the last decade are:

- The occurrence of the commodity super cycle between 2005 and 2009. In this super cycle the prices of numerous commodities, including maize, increased rapidly to unprecedented levels.

- Class mobility (from lower income to higher income classes) and the rising middle class during the past decade in South Africa are key drivers of changing consumption patterns in terms of increasing meat consumption.

- Changing general and trade policies increasingly require or depend on economic analyses of how they affect the agricultural sector in general and specifically, as the highest contributing subsector to agricultural GDP, how they affect the meat sector.

In light of the positive outlook for meat consumption and the dynamic consumer environment in South Africa, this study is aimed at better understanding the demand dynamics between the different meat products and income groups, allowing for improved anticipation of changes in meat consumption patterns driven by changes in income levels and/or relative meat prices in South Africa.

\section{Literature Overview}

A review of the current literature indicates that two basic theoretical approaches exist in estimating demand functions. The first starts with utility functions that satisfy certain axioms and conditions which are then maximised subject to a budget constraint, yielding simultaneous demand functions (Blanciforti, Green and King, 1986). This approach has been applied in the South African context by Cleasby and Ortmann (1991), Hancock, Nieuwoudt, Lyne (1984), and Du Toit (1982). A major drawback however is that all of these studies were conducted prior to 1994. In the 1990's, South African markets were deregulated, resulting in significant changes in market structure and price formation and hence, changes in consumer behaviour following deregulation are not captured in these elasticities. 
The second approach starts with an arbitrary demand system on which restrictions, consistent with demand theory, are imposed. This approach, specifically the Linear Approximation (LA) of the Almost Ideal Demand System (AIDS), first developed by Deaton and Muellbauer in the early 1980's, represents one of the most widely used demand systems and was also chosen for this study. The AIDS model has been applied to the meat complex (including, in varying combinations the product aggregates beef, mutton, pork, poultry and fish) in Australia (Cashin, 1991), Great Britain (Tiffin and Tiffin, 1999), Greece (Lazaridis, 2003), Jordan (Jabarin, 2005), South Korea (Henneberry and Hwang, 2007), China (Liu, Parton, Zhou and Cox, 2009) and Colombia (Ramirez, 2013) to name a few. Among these studies the expenditure elasticity of beef varied between 0.87 and 2.33 , with the majority of the estimates greater than 1 (Cashin, 1991; Tiffin and Tiffin, 1999; Jabarin, 2005; Henneberry and Hwang, 2007; Liu et al., 2009; Ramirez, 2013). For lamb and pork the expenditure elasticity results were divergent due to culture-related differences in consumption patterns. The expenditure elasticity for poultry varied between 0.06 and 1.78 in the studies mentioned above with the majority of the estimates being less than 1 (Cashin, 1991; Jabarin, 2005; Henneberry and Hwang, 2007; Liu et al., 2009; Ramirez, 2013). The uncompensated (Marshallian) own-price elasticities for beef varied between -0.76 and -1.75 , with the majority of the studies citing estimates greater than 1 in absolute value (Cashin, 1991; Tiffin and Tiffin, 1999; Henneberry and Hwang, 2007; Liu et al., 2009; Ramirez, 2013). Similar to the expenditure elasticities, the own-price elasticities for mutton and pork, estimated in the studies mentioned above, are divergent due to differences in consumption patterns across the countries. The own-price elasticities for poultry varied from -0.26 to -1.55 , with half of the estimates less than 1 in absolute value (Cashin, 1991; Lazaridis, 2003; and Henneberry and Hwang, 2007). It is important to keep in mind, that the widely varying economic conditions across countries also contributes towards greatly varying estimates of the elasticities of demand (Ramirez 2013). Note, that most of these studies have used aggregate commodities in the analysis of the AIDS model due to the nature of market-level data (Cashin 1991). In his study, Cashin (1991) elaborated on this approach by additionally modelling the demand for disaggregated products (ham, bacon and fresh pork) in order to analyse how the demand for the aggregate of pork products reflects the demand for the selected disaggregated pork products.

The work of Deaton and Muellbauer (1980) was first applied in the South African context by Taljaard (2003). He included beef, chicken, pork and mutton in the demand system after eggs were found to be separable from the group of meats. Restricted Seemingly Unrelated Regression (RSUR) methods were used to estimate the demand system, based on annual data from 1970 to 2000 . The study conducted by Taljaard in 2003 also represents the most recent extensive meat demand study in South Africa. Whilst the methodology applied in this context is similar to that used by Taljaard, the LA/AIDS model estimated in this study will draw on monthly data from 2008 to 2014, yielding short term elasticities that reflect the recent changes in the South African consumer environment, as well as the global implications following the commodity super cycle. The expenditure and cross-price elasticities estimated by Taljaard (2003) will be discussed in more detail when contextualising the elasticities estimated in this study. 


\section{Objectives of the study}

In light of the changes that have occurred over the past decade, both on the supply and demand side, the main objective of this study is to gain an improved understanding of meat consumption and price dynamics in South Africa through the estimation of product specific expenditure and cross-price elasticities. A linear approximation of the almost ideal demand system will be used to estimate the elasticities for the South African meat complex. The impact of changes in the South African consumer market on meat demand will also be analysed at the hand of the estimated elasticities. Due to its relative importance within the South African meat complex, specific attention is afforded to the poultry sector, which is disaggregated into two groups based on relative price and demand differences (similar to the disaggregation of pork products in the study by Cashin (1991)). The details of this disaggregation are elaborated on in the data discussion in Section 5.

\section{Methodological overview}

The AIDS methodology is based on an implicit two-stage budgeting procedure where disposable income is allocated to broad groups of goods (food, transport, entertainment, etc.) in the first stage, before being dedicated to a group like food and further allocated to individual food commodities (rice, maize meal, poultry, vegetables, etc.) in the second stage. The implication of a two-stage budgeting procedure is that only the information for the stage of interest is required in order to perform analysis of the distribution of disposable income. A necessary and sufficient condition for the two-stage budgeting procedure is the weak separability of utility functions of individual meats in a broader group. Taljaard (2003) performed a test for separability between eggs and beef, mutton, pork and poultry and found that eggs were separable from the other meat products. It was impossible to test for separability in this study since the data were gathered from difference sources (see the subsequent data discussion section) and the separability is therefore assumed based on the work of Taljaard (2003).

The theoretical specification of the AIDS model is described as follows:

The $\mathrm{i}^{\text {th }}$ equation of the AIDS model is defined as:

$w_{i t}=\alpha_{i}+\sum_{j=1}^{n} \gamma_{i j} \ln p_{j t}+\beta_{i} \ln \left(\frac{X_{t}}{P_{t}}\right)+u_{i t} \quad \mathrm{i}=1,2, \ldots, \mathrm{n}$

Where

- $w_{i t}$ is the expenditure share of the $\mathrm{i}^{\text {th }}$ good at time $\mathrm{t}$.

- $p_{j t}$ is the real price of the $\mathrm{j}^{\text {th }}$ good at time $\mathrm{t}$.

- $\ln \left(X_{t}\right)$ is the natural log of total expenditure.

- $u_{i t}$ is the random or error term, and

- $\ln \left(P_{t}\right)$ is the translog price index defined by: 
$\ln P_{t}=\alpha_{0}+\sum \alpha_{j} \ln p_{j}+\frac{1}{2} \sum_{i=1}^{n} \sum_{j=1}^{n} \gamma_{i t} \ln p_{i t} \ln p_{j t} \mathrm{t}=1,2, \ldots, \mathrm{T}$

However, the price index specified above makes the system non-linear. The AIDS therefore needs to be linearized in order to simplify estimation procedures. Deaton and Muellbauer (1980) suggested the Stone's price index in order to replace the translog price index as defined in (2).

$\operatorname{Ln} P=\sum_{i=1}^{n} w_{i, t} \ln p_{i, t}$

Eales and Unnevehr (1998) further indicate that the Stone's price index causes a simultaneity problem in that the expenditure weight at time $t$ for good $i$ appears on both sides of the LA/AIDS specification. The lagged expenditure weight would solve this problem and specify the LA/AIDS as follows:

$w_{i t}=\alpha_{i}+\sum_{j=1}^{n} \gamma_{i j} \ln p_{j t}+\beta_{i}\left(\operatorname{Ln} X-\sum_{i=1}^{n} w_{i, t-1} \ln p_{i, t}\right)+u_{i t} \quad \mathrm{i}=1,2, \ldots, \mathrm{n}$

Theoretical demand restrictions need to be adhered to and include the adding-up, homogeneity and symmetry restrictions. These restrictions can be formulated and imposed on the model as follows:

Adding up: $\quad \sum_{i} \alpha_{i}=1, \quad \sum_{i} \gamma_{i j}=0, \quad \sum_{i} \beta_{i}=0$

Homogeneity: $\sum_{j} \gamma_{j}=0$

Symmetry: $\quad \gamma_{i j}=\gamma_{j i}$

Furthermore, since monthly data are used in this study, provision needs to be made for seasonality and trends. The expenditure weight equations in (4), to be estimated by the LA/AIDS, are therefore adjusted as follows:

$$
\begin{aligned}
& w_{i t}=\alpha_{i}+\sum_{j=1}^{n} \gamma_{i j} \ln p_{j t}+\beta_{i}\left(\operatorname{Ln} X-\sum_{i=1}^{n} w_{i, t-1} \ln p_{i, t}\right)+a_{i}^{c} \cos \frac{2 \pi t}{4}+a_{i}^{S} \sin \frac{2 \pi t}{4}+ \\
& a_{i}^{t} \cdot t+u_{i t}
\end{aligned}
$$

Elasticities are calculated using the estimated LA/AIDS parameters as described below. Elasticities only have meaning at a certain point, and for the purpose of this analysis they are calculated at the mean prices and weights for the various meat products.

1) Income elasticities:

$e_{i}=\frac{\beta_{i}}{w_{i}}+1$

2) Marshallian demand elasticities: 
$\epsilon_{i j}^{M}=\frac{\gamma_{i j}-\beta_{i}\left(w_{j}-\beta_{j} \ln \left(\frac{X}{P}\right)\right)}{w_{i}}-\delta_{i j}$

where

$$
\begin{aligned}
\delta_{i j} & =1 \text { if } i=j \\
& =0 \text { otherwise }
\end{aligned}
$$

3) Hicksian demand elasticities:

$$
\epsilon_{i j}^{H}=\epsilon_{i j}^{M}+w_{j} \cdot e_{i}
$$

\section{Data discussion}

Four different meat types are included in the analysis, namely beef, pork, poultry and mutton. The special focus on poultry entails the disaggregation of the aggregate of poultry products into two categories, the first being Individually Quick Frozen (IQF) portions and the other referring to all other chicken meat products. The disaggregation is based on the assumption that the demand dynamics for the two categories are different, owing to the fact that they are often consumed by different income groups, whilst different cuts are also preferable in different regions globally due to traditional tastes and preferences. This observation stems from the assumption that meat products of a certain animal are no longer homogenous since demand for certain cuts is higher than for others in certain countries. Within the globalised environment, trade allows for the maximisation of total carcass value by marketing different cuts in different geographical locations, taking advantage of demand differences and the related price differentials.

The product mix necessitated the collection of data from various sources, as indicated in Table 1. The data were collected in monthly frequencies, from January 2008 to September 2014, and prices and consumption are represented at national level.

Table 1- Data Sources

\begin{tabular}{|l|l|l|}
\hline Nominal Prices & Source \\
\hline Beef & Carcass prices ex-abattoir & Red Meat Abattoir Association (RMAA) \\
\hline Pork & Carcass prices ex-abattoir & RMAA \\
\hline Poultry & Producer Prices - IQF portions & RMAA \\
\hline & Producer Prices - Frozen whole bird & South African Poultry Association (SAPA) \\
\hline Consumption & & SAPA \\
\hline Beef & Slaughters & Source \\
\hline & Imports & Red Meat Levy Administration \\
\hline Sheep & Average animal weight & Trademap / ITC database / SARS \\
\hline & Slaughters & RMAA \\
\hline
\end{tabular}




\begin{tabular}{|c|c|c|}
\hline & Average animal weight & RMAA \\
\hline \multirow[t]{3}{*}{ Pork } & Slaughters & Red Meat Levy Administration \\
\hline & Imports & Trademap / ITC database / SARS \\
\hline & Average animal weight & RMAA \\
\hline \multirow[t]{3}{*}{ Poultry } & Weekly slaughters & SAPA \\
\hline & Imports & Trademap / ITC database / SARS \\
\hline & Distribution of Market sales & SAPA \\
\hline
\end{tabular}

As the monthly consumption and price data required for the various meat types included in the analysis were not readily available, a proxy was calculated as follows: the prices of beef, mutton and pork were averaged across various carcass prices. Poultry IQF prices were taken as quoted and the whole frozen chicken price was taken as a proxy for the price of the other poultry components. Monthly consumption figures were estimated for beef, sheep and pork meat using national slaughter numbers and weighted average carcass weights to derive production levels based on the number of animals slaughtered in each category. It is important to note that commercial slaughter numbers are used and therefore the informal market is not accounted for in the consumption figures. Net imports of meat were added to derive total consumption figures, which in turn were converted to a per capita per month basis using population estimates (StatsSA, 2015). Within the poultry sector, weekly slaughter numbers reported by SAPA (2015) were converted to monthly estimates, which in turn were allocated to IQF portions and 'other poultry' consumption based on the marketed product mix published by SAPA (2015).

Effectively the AIDS model will solve the weight equations specified in equation (8) by means of a regression. Since time series data are used, a test for stationarity needs to be performed on all the expenditure weights and price time series in order to avoid spurious regression results from non-stationary time series. The Augmented Dickey Fuller test is used as the test for stationarity. The null hypothesis is specified as follows:

$\mathrm{H}_{0}$ : The time series has one unit root (and is therefore non-stationary); is tested against the alternative hypothesis

$\mathrm{H}_{\mathrm{a}}$ : The time series does not have a unit root (and is therefore stationary).

If the null hypothesis is rejected at a 0.05 significance level when the relevant p-value is less than 0.05 , it is then concluded that the time series does not have a unit root and is therefore stationary. If however the null hypothesis cannot be rejected, the same test is performed on the differenced (Dif) time series. The differenced time series is then used in the estimation of the AIDS model. The results of stationary tests are summarized in Table 2: 
Table 2 - Stationarity Test Results

\begin{tabular}{|l|l|l|}
\hline Variable name & p-value & Rejection of $\mathbf{H}_{\mathbf{0}}$ \\
\hline Beef expenditure weight & 0.0008 & Reject \\
\hline Mutton expenditure weight & 0.0008 & Reject \\
\hline Pork expenditure weight & 0.0008 & Reject \\
\hline Poultry - IQF expenditure weight & 0.0009 & Reject \\
\hline Poultry - Rest expenditure weight & 0.0012 & Reject \\
\hline Beef Price & & Do not Reject \\
\hline Dif(Beef Price) & 0.43 & Reject \\
\hline Mutton Price & $<0.0001$ & Do not Reject \\
\hline Dif(Mutton Price) & 0.728 & Reject \\
\hline Pork Price & $<0.0001$ & Do not Reject \\
\hline Dif(Pork Price) & 0.3874 & Reject \\
\hline Poultry - IQF Price & $<0.0001$ & Do not Reject \\
\hline Dif(Poultry - IQF Price) & 0.2353 & Reject \\
\hline Poultry - Rest Price & $<0.0001$ & Do not Reject \\
\hline Dif(Poultry - Rest Price) & 0.1552 & Reject \\
\hline
\end{tabular}

From Table 2, it is concluded that the AIDS model will draw on stationary expenditure weight data and the first difference of meat price data.

\section{Results}

\subsection{General model results}

In order to adhere to the adding-up condition in equation (5), one weight equation needs to be dropped in estimating the parameters for the LA/AIDS. All the restrictions in equations (5), (6) and (7) are then used to calculate the parameters for the dropped equation. Which specific equation is dropped does not change the results and for this study the beef weight equation was dropped.

The expenditure weight equations were estimated as specified in equation (8) and the restrictions in (5), (6) and (7) were imposed on the system. The LA/AIDS parameters were estimated using the proc syslin procedure in SAS and the ITSUR (Iterative Seemingly Unrelated Regression) estimation procedure was used to estimate the equation parameters. The SUR (Seemingly Unrelated Regression) method of estimation, a generalization of ordinary least squares (OLS) estimation which improves the efficiency of the estimated parameters, was used.

All the restrictions imposed on the model could not be rejected at a 0.05 significance level. The model cross-correlations in Table 3 illustrate the relationship between the estimated expenditure share equations (as in (8)) for each meat type. Although they are not elasticities, these cross-correlations provide an indication of the nature of the relationship between the different meat groups. A negative cross-correlation is observed between most meat groups, which indicates a substitutive relationship in the expenditure share of the various meats. The 
South African pork market remains very small, partly due to religious and cultural reasons. Also, the range of products is greatly diversified, with some being consumed fresh by lower income consumers and others as high-value processed products such as bacon which would typically be consumed by the same high income consumers that typically consume lamb. In this instance, these products may not always be considered substitutes by the consumer. The substitute- and complementary relationships between the various meats will however be discussed in more detail at the hand of the calculated cross-price elasticities.

Table 3 - Model cross-correlations

\begin{tabular}{|l|l|l|l|l|}
\hline & Poultry - IQF & Poultry - other & Pork & Sheep \\
\hline Poultry - IQF & 1.00000 & -0.52673 & -0.03865 & -0.47353 \\
\hline Poultry - other & -0.52673 & 1.00000 & -0.25618 & -0.19628 \\
\hline Pork & -0.03865 & -0.25618 & 1.00000 & $\mathbf{0 . 1 5 0 6 3}$ \\
\hline Sheep & -0.47353 & -0.19628 & $\mathbf{0 . 1 5 0 6 3}$ & 1.00000 \\
\hline
\end{tabular}

Figure 1 presents the calculated expenditure weights used in the LA/AIDS model. Total poultry expenditure is the largest with IQF portions and other poultry products contributing roughly equal parts. The second highest expenditure is for beef followed by mutton and pork expenditure which have the lowest and similar magnitudes of expenditure share over time.

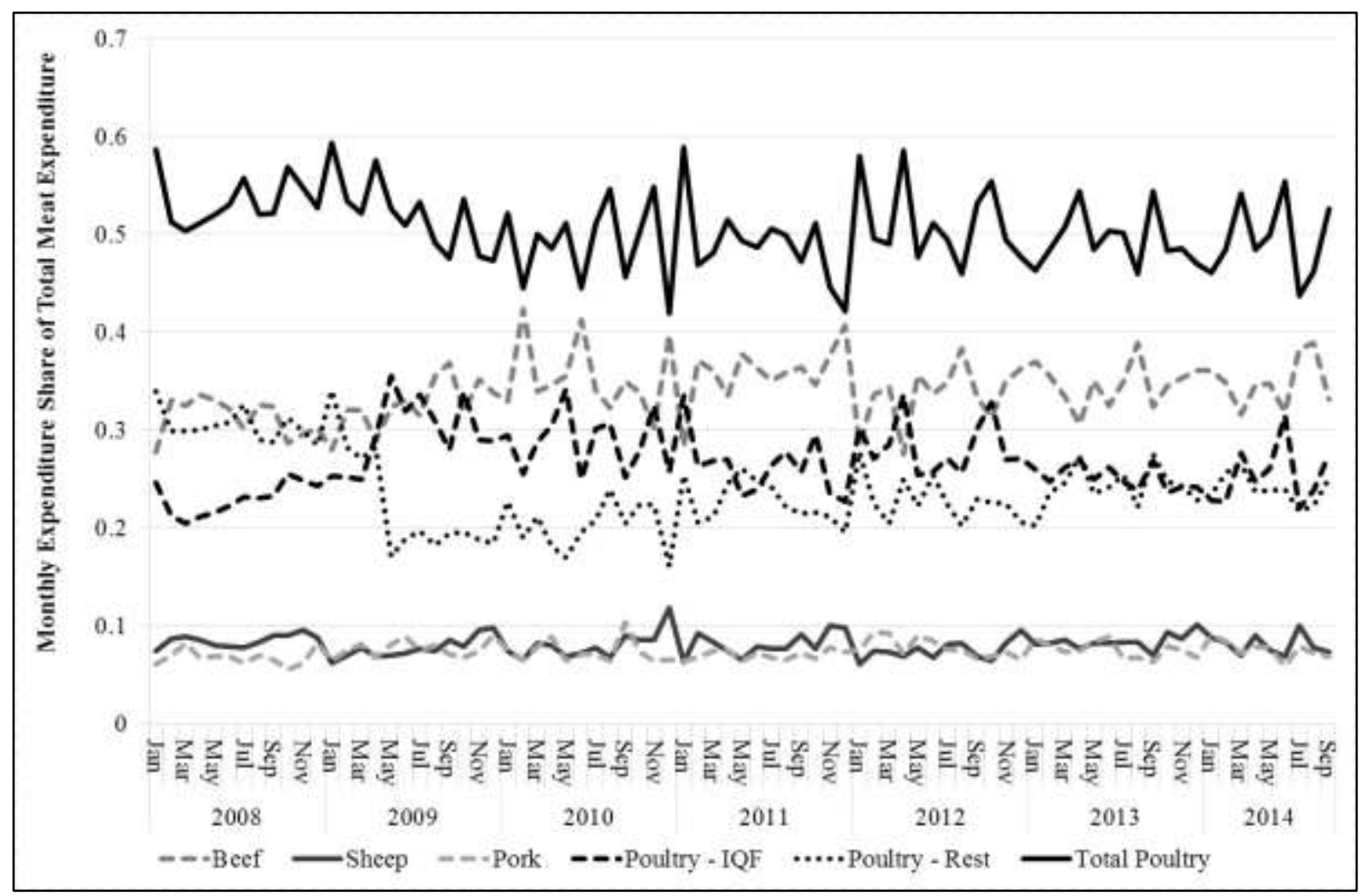

Figure 1: Expenditure weights

Source: own calculations 


\subsection{Expenditure elasticities}

The expenditure elasticity of meat product $i$ is defined as the percentage change in the quantity demanded of meat product $i$ as a result of a one percent change in total expenditure on meat products (not total expenditure on all goods). For pork, mutton and beef, the expenditure elasticities are in-line with expectations. Mutton is the most expensive type of meat (on a R/kg basis, averaged over all products or cuts included in the mutton aggregate) and an expenditure elasticity of 1.07 classifies mutton as a luxury. A beef and pork expenditure elasticity of 0.8 and 0.44 respectively (Table 4) classifies them both as normal goods. Beef is more expensive than pork on a Rand per kilogram basis (averaged over all products included in the beef and pork aggregates) and a large share of food expenditure of the South African population is dedicated to beef; beef is historically more volatile with respect to expenditure changes than pork.

Table 4 - Expenditure Elasticities

\begin{tabular}{|l|l|}
\hline Meat & Expenditure Elasticity \\
\hline Poultry - IQF & 1.17 \\
\hline Poultry - Other & 1.24 \\
\hline Pork & 0.44 \\
\hline Mutton & 1.07 \\
\hline Beef & 0.80 \\
\hline
\end{tabular}

Poultry represents the cheapest and most accessible meat protein, resulting in the prior expectation of a low expenditure elasticity for poultry products, implying that it is a necessity. In Table 4 both poultry meat categories have an expenditure elasticity greater than 1 which is indicative of a luxury product. If the expenditure on meat increases by $1 \%$, the expenditure on IQF portions and other poultry products increases by $1.17 \%$ and $1.24 \%$ respectively.

Hancock et al. (1984) used annual data from 1962 to 1981 in their South African meat demand analysis and found the estimated poultry income elasticity to be 1.12 , whereas pork, beef and mutton income elasticities were estimated at $0.73,0.71$ and 0.44 respectively; also classifying poultry as a luxury product. Taljaard (2003), who also used the LA/ADIS model to estimate expenditure elasticities for mutton (1.182), beef (1.243), pork (0.948) and chicken (0.526), used annual data from 1970 to 2000. Elasticity calculations based on annual data yield long term elasticity estimates whereas this study was based on monthly data from 2008 to 2014 , resulting in short term elasticity estimates. The mutton expenditure elasticity coefficient estimated in this study is comparable to the long run expenditure elasticity estimated by Taljaard (2003); however, higher expenditure elasticities for beef and pork were obtained by Taljaard (2003) and a lower expenditure elasticity for poultry.

This divergence from expectations related to long term and short term elasticities was previously found in a study in the United States by Goodwin (1992), who found that expenditure elasticities for poultry and fish were small (necessities) before a significant economic shift and high (luxuries) after this shift took place. The timing of the change in elasticities was consistent with consumption pattern changes to include more convenience and processed products and health concerns with red meat (Goodwin, 1992). The so-called 
significant economic shift in the South African context is the change in the consumer base included in the analysis. Figure 2 illustrates this shift as the phenomenon known as class mobility. Consumers consistently moved from lower income categories to higher income categories in the past 10 to 15 years, giving rise to a larger and stronger middle class, expectantly changing consumption patterns at large. The expenditure elasticities obtained in this study are therefore considered plausible.

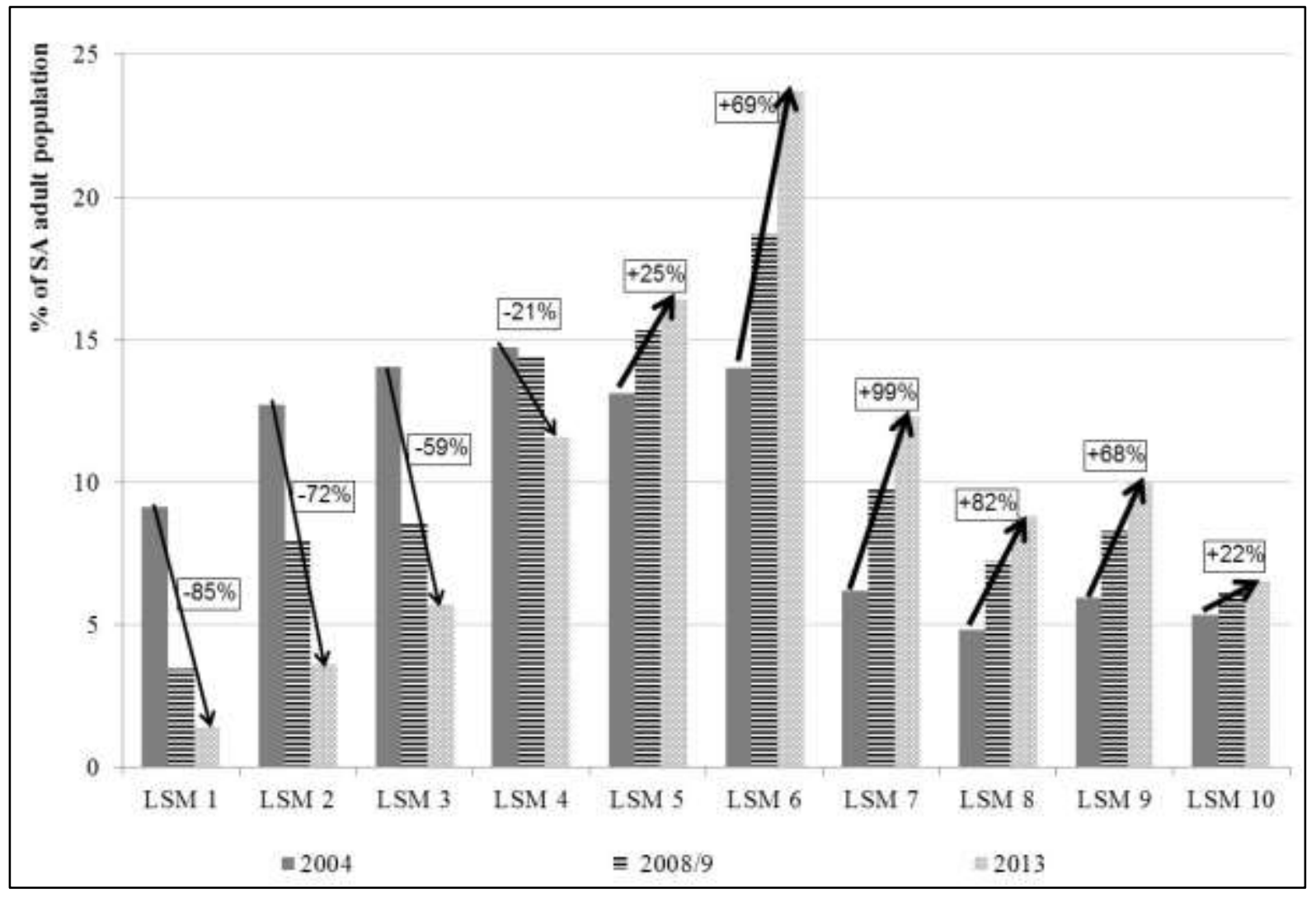

Figure 2: Class mobility in South Africa

Source: SAARF All Media and Products Surveys (AMPS) 2004 to 2013

Using the South African Audience Research Foundation (SAARF) LSM (Living Standards Measure) socio-economic classification of adults (older than 15 years), South African consumers are classified into 10 categories ranging from 1 (poorest) to 10 (wealthiest), and by comparing the LSM classifications over time, the class mobility is demonstrated. Nearly $11 \%(10.7 \%)$ of the population is in LSM category 1-3, classified as the poor or marginalised consumers and consisting of about 4 million adults. About 19 million adults (51.7\%) find themselves in the middle class or so-called mass market in LSM categories 4 to 6 . Around 8 million adults $(21.1 \%)$ are classified in LSM categories 7 and 8, called the upper middle class and the remaining 6 million adults (16.5\%) are classified in LSM categories 9 and 10, the wealthy consumers (BFAP, 2014). Figure 3 below presents the expenditure changes for low, middle and high income groups between the 2005/2006 and 2010/2011 income and expenditure surveys. 


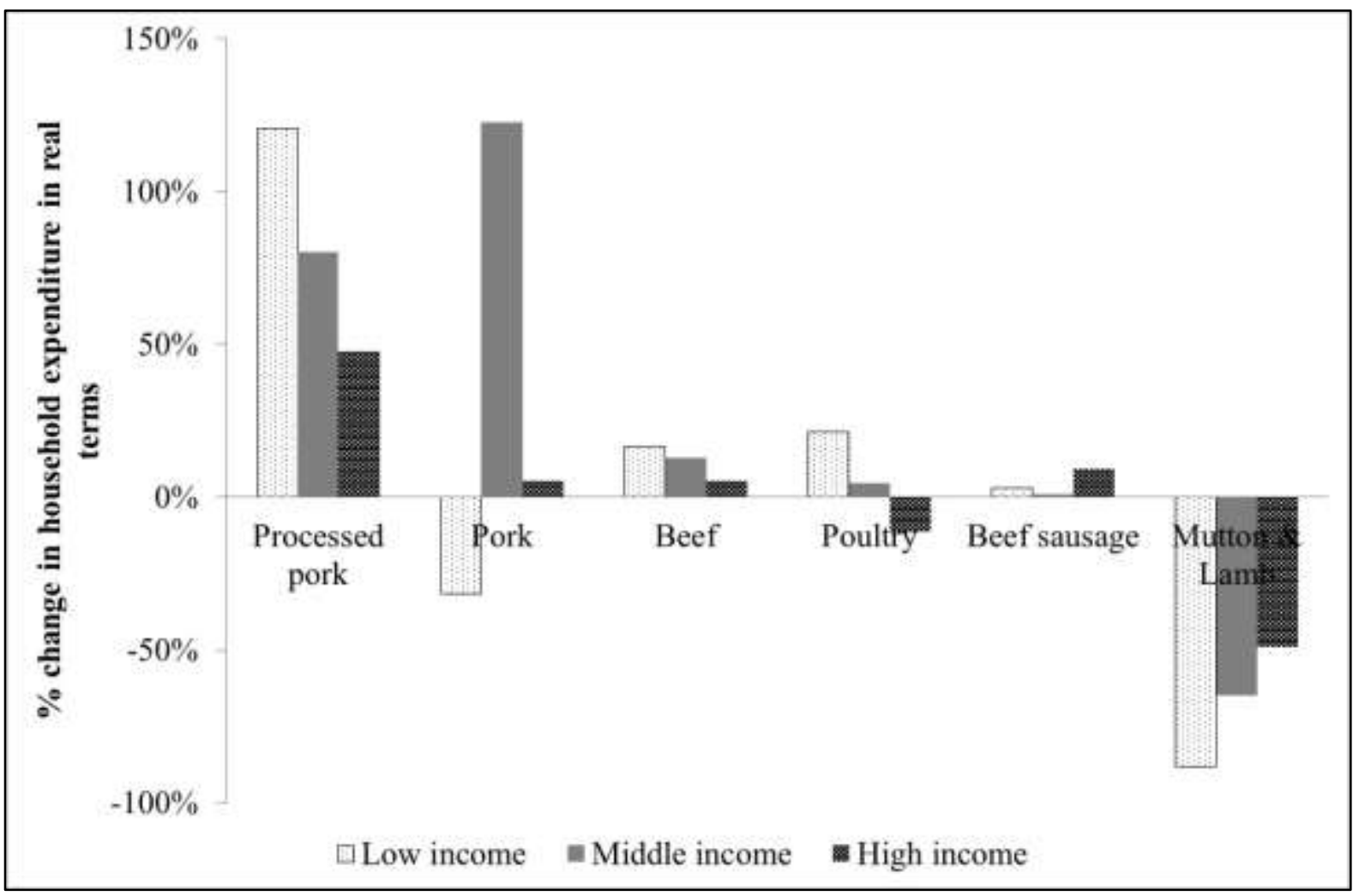

Figure 3 - Changes in estimated real household-level expenditure - 2010/2011 to 2005/2006 Source: Own calculations based on StatsSA IES 2005/06 and 2010/11 data

Total expenditure increased between $30 \%$ and 50\% across the income groups with the largest increase for the middle income group. Expenditure on food and non-alcoholic beverages increased only for low and middle income households. The real expenditure on poultry increased only for lower and middle income consumers and that for fresh pork only for middle and high income consumers. Interestingly, real expenditure on processed pork increased for all income groups. Even though pork has the lowest estimated expenditure elasticity, the greatest increases in household expenditure were recorded for processed pork products, implying that other factors such as indulgence or convenience drive the increases in expenditure. For mutton and lamb however the real expenditure decreased for all income groups.

South African urban retail data collected by StatsSA illustrates that frozen chicken portions, polony, tinned fish, whole chicken and fresh chicken portions are the cheapest group of meat products. The 'mid-range' of products in terms of affordability consists of beef brisket, beef chuck, beef mince and pork chops. On average, these meat options were about $120 \%$ more expensive than frozen chicken portions during the period January 2008 to April 2015. The most expensive meat cuts included in the sample are beef rump steak, lamb and beef T-bone. On average, these meat options are about $230 \%$ more expensive than frozen chicken portions. This retail price spread across meat products in urban areas in South Africa implies that poor consumers have limited options in terms of affordable meats. 
When considering that a large share of the population is poor $(10.7 \%-62.4 \%)$ and depends on poultry meat for any protein inclusion in their diets, a decrease in $1 \%$ expenditure devoted to poultry or food in general can likely cause a poor household not to buy (and consume) any poultry meat. Within this income group, meat itself is a luxury product and given that IQF's and other poultry products are two of the most affordable meats, they are most affected by a change in expenditure. Given the previously mentioned religious and cultural inhibitions to pork meat, poultry is likely substituted with pulses and even starches since other meats are not really affordable.

Expenditure equals quantity consumed multiplied by the price of a given product; therefore, the income of a given household is implied by the quantity of a product that can be afforded given a certain price. For a lower income to poor household, the change in quantity consumed of poultry products will be more severe given a change in price. In the South African context, given the information and expenditure share analysis above, poultry meat can be classified as a luxury product for a significant segment of the population. This result is further supported by the fact that other poultry products have an even higher expenditure elasticity than IQF portions, which are the cheaper forms of poultry meat.

\subsection{Cross-price elasticities}

The compensated own-price elasticity is defined as the percentage change in quantity demanded of meat $i$, as a result of a $1 \%$ increase in the price of meat $i$ (excluding the income effect). The compensated own-price elasticity (containing only the price effect) was the largest for mutton (-0.96), followed by pork (-0.72), IQF's $(-0.61)$, other poultry $(-0.43)$ and lastly beef (-0.11) (see Table 5). The own-price elasticities are all negative and between zero and one, indicating that meat products are normal goods. The own-price elasticity for mutton is very close to one supporting the fact that mutton is seen as luxury product in South Africa. Considering the cross-price elasticities, the consumption of mutton shows the largest substitution effect with respect to the price of pork, and conversely, substitutability between the quantity of pork consumed and the price of mutton, is the second highest $(0.43)$. The consumption of IQF portions shows high substitutability with respect to the price of mutton $(0.35)$, other poultry products $(0.33)$, pork $(0.28)$ and beef $(0.11)$. Other poultry consumption is also quite responsive to the price of IQF portions.

Cross-price elasticity of product $i$ with respect to $j$ is defined as the percentage change in the quantity demanded of meat $i$, as a result of a $1 \%$ change in the price of meat $j$. Cross-price elasticities should be interpreted with care; whilst undoubtedly useful in explaining consumer behaviour, there will always be factors that remain unaccounted for. For example, the prices of both pork and chicken are influenced greatly by import parity price movements hence, changes in the exchange rate would cause similar price changes in both products. Therefore, some of the evident 'substitution effects' could also be as a result of other exogenous drivers that impact on prices and consumption of both meat types simultaneously.

Nonetheless, it is interesting to note that the highest cross-price elasticities in the meat complex (with the exception of the cross-price effects between mutton and pork) are related 
to IQF portion consumption with respect to the other meat prices. To this point, recent consumer research for the South African red meat industry (commissioned by Red Meat Research Development South Africa (RMRD SA)) indicated a general trend of replacing some red meat with chicken meat. For example, the share of consumers who indicated that they consumed less beef and more chicken varied between $68 \%$ and $79 \%$, while the share of consumers who indicated that they consumed less mutton/lamb and more chicken varied between $71 \%$ and $74 \%$. In all cases the share of consumers substituting some red meat with chicken decreased towards the wealthier segments. Affordability was the main driver behind the partial substitution of red meat with chicken. For example, the share of consumers perceiving beef as affordable varied from $10 \%$ for low-income consumers to $55 \%$ for highincome consumers, while $14 \%$ to $19 \%$ of consumers viewed mutton/lamb as being affordable. A large share of consumers (52\% to 63\%) agreed that mutton/lamb is a luxury product within their households (Vermeulen and Schönfeldt, 2015).

The substitutability of mutton and beef consumption with respect to the price of IQF portions is 0.1 and 0.14 respectively. The other cross-price elasticities are very small (less than 0.1 ). All cross-price elasticities are positive, in-line with the expectation that meat products are substitutes, with the exception of beef consumed as a response to the price of pork (-0.11) and quantity of pork consumed as a result of a change in the beef price (-0.02). These negative cross-price elasticities are indicative of the fact that pork and beef meat are complements. The complementary relationship implies the following: if the beef or pork price decreases, more beef and pork will be consumed; conversely if the pork or beef price increases less pork and beef will be consumed. Though this result may be somewhat counter intuitive, the unique characteristics of pork consumption in South Africa result in a number of factors other than prices and income levels influencing pork consumption, which may drive these results.

Table 5 - Compensated (Hicksian) price elasticities

\begin{tabular}{|l|l|l|l|l|l|}
\hline & Poultry-IQF Q & Poultry-Other Q & Pork Q & Mutton Q & Beef Q \\
\hline Poultry-IQF P & $\mathbf{- 0 . 6 1}$ & 0.30 & 0.08 & 0.10 & 0.14 \\
\hline Poultry-Other P & 0.33 & $\mathbf{- 0 . 4 3}$ & 0.02 & 0.04 & 0.02 \\
\hline Pork P & 0.28 & 0.08 & $\mathbf{- 0 . 7 2}$ & 0.47 & -0.11 \\
\hline Mutton P & 0.35 & 0.13 & 0.43 & $\mathbf{- 0 . 9 6}$ & 0.05 \\
\hline Beef P & 0.11 & 0.02 & -0.02 & 0.01 & $\mathbf{- 0 . 1 1}$ \\
\hline
\end{tabular}

According to economic theory, consumer flexibility and consumption elasticities increase over time as fixed variables in the short run become more elastic in the long run. It was found, however, that the own-price elasticities estimated in this study were higher than the long term elasticities estimated by Taljaard (2003) which were -0.161, $-0.193,-0.305$ and 0.277 for beef, chicken, pork and mutton, respectively. Another study by Hancock et al. (1984) estimated long term own-price elasticities higher than the ones obtained in this study, namely $-0.96,-1.66,-1.86,-1.93$ for beef, chicken, pork and mutton, respectively. Given the structural changes with respect to price formation and demand structures in South Africa as discussed in Section 2, the results of this study are not directly comparable to Taljaard's or Hancock et al.'s results. The short term own-price elasticities estimated in this study remain realistic when interpreted in the modern context. 
The estimated uncompensated own-price elasticities are $-1.04,-0.93,-0.75,-0.72,-0.38$ for mutton, IQF portions, pork, other poultry and beef, respectively (Table 6). A number of uncompensated cross-price elasticities are negative which is contrary to the expectation of substitutability between the different meats. According to Taljaard (2003), reasons for these negative signs include:

- When the relative disposable income of a given South African household changes (positive or negative), the first decision reached is what proportion of this change to increase/cut spending or savings with. Only when this decision is reached the change in spending is attributed to goods and services of which meat is only one category of goods. Since meat is a normal or luxury good for the majority of the South African population, a rise in real disposable income will lead to an increase in the consumption of meat. The uncompensated elasticities include this positive income effect.

- Secondly, South African consumers might prefer to consume certain meat products simultaneously and since the income effect is included in the uncompensated crossprice elasticity, a change in disposable income might change the consumption of multiple types of meat simultaneously.

Table 6 - Uncompensated (Marshallian) price elasticities

\begin{tabular}{|l|l|l|l|l|l|}
\hline & Poultry-IQF Q & Poultry-Other Q & Pork Q & Mutton Q & Beef Q \\
\hline Poultry-IQF P & $\mathbf{- 0 . 9 3}$ & 0.02 & -0.01 & 0.01 & -0.26 \\
\hline Poultry-Other P & 0.00 & $\mathbf{- 0 . 7 2}$ & -0.07 & -0.06 & -0.40 \\
\hline Pork P & 0.16 & -0.03 & $\mathbf{- 0 . 7 5}$ & 0.43 & -0.26 \\
\hline Mutton P & 0.06 & -0.12 & 0.35 & $\mathbf{- 1 . 0 4}$ & -0.31 \\
\hline Beef P & -0.11 & -0.17 & -0.08 & -0.05 & $\mathbf{- 0 . 3 8}$ \\
\hline
\end{tabular}

The uncompensated price elasticities estimated by Taljaard (2003) were also not consistent with a priori expectations for substitute products, hence the reasons for divergence from expectations above. It is interesting to note that compensating for the income effect causes the most significant reduction in the own-price elasticities for IQF portions and other poultry products (comparing Table 5 with Table 6). This further emphasizes the point that income and expenditure changes largely affect the own-price elasticity and therefore the consumption of poultry products.

\section{Conclusion}

In completing this analysis, expenditure-, own-price- and cross-price elasticities were estimated using the LA/AIDS demand system model for the South African meat complex including beef, mutton, pork and poultry. Special focus was placed on poultry which was split up into IQF portions and other poultry products. Expenditure elasticities for IQF portions, other poultry products, pork, mutton and beef were 1.17, 1.24, 0.44, 1.07 and 0.8 respectively. An interesting and somewhat counter-intuitive result is the fact that the poultry products were classified as luxury products (normally associated with relatively expensive 
products) while it is widely known that poultry is the most affordable animal protein. Within the lower income groups where a significant share of poultry products are consumed however, it can be argued that poultry, as the only affordable choice of meat, can be considered a luxury relative to the alternative, namely traditional starches and pulses. These consumers depend on poultry products for any meat protein inclusion in their diets.

The compensated own-price elasticities were estimated as $-0.61,-0.43,-0.72,-0.96$ and -0.11 for IQF portions, other poultry products, pork, mutton and beef, respectively, meeting $a$ priori expectations of negative own-price elasticities. Cross-price elasticities were particularly high between mutton and pork, possibly due the complicated nature of the South African pork market and the fact that higher income consumers or so-called established consumers consume the largest proportions of both mutton and pork. Other high cross-price elasticities were the substitution effects between the consumption of IQF portions and the price of the other meat products. A study by Vermeulen and Schönfeldt (2015) confirms this substitutability as large proportions of South African consumers confirmed to substitute beef and mutton with poultry on the basis of affordability (or relative prices).

The estimated elasticities enable a better understanding of the meat complex in the modern context: the interplay between relative prices, income/expenditure changes, product substitutability as well as current consumption trends. Demand elasticities for the meat complex are also useful in modelling applications in order to reflect the meat market more accurately. The elasticities for IQF portions and other poultry products can prove particularly useful in measuring the impacts of policies like the AGOA trade agreement (which allows 65 000 additional tons of IQF portions to enter the South African market at normal duty rates (Business Day, 2016)). Different equilibrium models can use these elasticities in order to model the impacts of trade agreement and policy changes on the local consumer market. Producer organisations and marketers can use this information to make informed strategic decisions.

The implications and uses of the results are not only limited to modelling applications but will have the potential to further inform policy decisions in South Africa. Population growth, urbanization and income growth in developing countries are fuelling increases in the demand for meats. This expected change in millions of people's diets in South Africa can improve the well-being and health of the rural poor population in South Africa (Degaldo, Rosegrant, Steinfeld, Ehui and Courbois, 2003).

\section{References}

Abstract of Agricultural Statistics. 2016. Department of Agriculture, Forestry and Fisheries $(D A F F)$. Pretoria, South Africa.

Bureau for Food and Agricultural Policy. 2014. BFAP Baseline 2014. Pretoria, South Africa.

Blanciforti, L. A., Green, R. D. and King, G. A. 1986. U.S. Consumer Behavior Over the Postwar Period: An Almost Ideal Demand System Analysis. Giannini Foundation Monograph Number 40. 
Business Day. 2016. Chicken imports end Agoa impasse. Johannesburg, Gauteng, South Africa. Available at www.bdlive.co.za/business/trade/2016/03/03/chicken-importsend-agoa-impasse.

Cashin, P. 1991. A Model of the Disaggregated Demand for Meat in Australia. Australian Journal of Agricultural Economics, 35(3), pp.263-283. Available at $<$ Go to ISI>://WOS:A1991JA99900002.

Cleasby, R.C.G. and Ortmann, G.F. 1991. Demand Analysis of Eggs in South Africa. Agrekon 30(1), 34-36.

Deaton, A. and Muellbauer, J. 1980. An Almost Ideal Demand System. The American Economic Review 70(3): 312-326.

Degaldo, C. L., Rosegrant, M., Steinfeld, H., Ehui, S. and Courbois, C. 2003. Livestock to 2020 - The Next Food Revolution. IFPRI. Washington DC.

Du Toit, J.P.F. 1982. 'n Ekonometriese ontleding van die vraag na en aanbod van vleis in Suid Afrika. Unpublished MBA thesis, University of Pretoria.

Eales, J. S. and Unnevehr, L. J. 1993. Simultaneity and structural change in U.S. meat demand. American Journal of Agricultural Economics 75: 259-268.

Goodwin, B. 1992. Multivariate gradual switching systems and the stability of US meat demands: a Bayesian analysis. Structural Change and Economic Dynamics 3(1): 155166.

Goddard, E.W. and Glance, S. 1989. Demand for Fats and Oils in Canada, United States and Japan. Canadian Journal of Agricultural Economics 37(3): 421-443.

Hancock, P.J., Nieuwoudt, W.L. and Lyne, M.C. 1984. Demand analysis of meats in South Africa. Agrekon 23(3): 26-29.

Henneberry, S.R. and Hwang, S. 2007. Meat demand in South Korea: An Application of the restricted Source-Differentiated Almost Ideal Demand System Model. Journal of Agricultural and Applied Economics 39(1): 47-60.

International Trade Centre (ITC). 2015. Trademap. Available at: http://www.trademap.org/Index.aspx

Jabarin, A.S. 2005. Estimation of meat demand system in Jordan: an almost ideal demand system. International Journal of Consumer Studies 29: 32-39.

Lazaridis, P. 2003. Household meat demand in Greece: A demand systems approach using microdata. Agribusiness 19(1): 43-59. Available at: http://dx.doi.org/10.1002/agr.10044.

Liu, H., Parton, K.A., Zhou, Z.Y. and Cox, R. 2009. At-home meat consumption in China: An empirical study. Australian Journal of Agricultural and Resource Economics 53(4): 485-501.

Ncube, M., Lufumpa, C.L. and Kayizzi-Mugerwa, S. 2011. The middle of the pyramid: Dynamics of the middle class in Africa. African Development Bank, Tunis. Available at 
http://www.afdb.org/fileadmin/uploads/afdb/Documents/Publications/The\%20Middle $\% 20$ of\%20the\%20Pyramid_The\%20Middle\%20of\%20the\%20Pyramid.pdf

Nieftagodien, S. and Van Der Berg, S. 2007. Consumption patterns and the black middle class: The role of assets. Bureau of Economic Research 2: 1-10.

OECD/FAO Agricultural Outlook. 2015. OECD-FAO Agricultural Outlook 2015, OECD Publishing, Paris.

Ravallion, M. 2010. The Developming World's Bulging (but Vulnerable) Middle Class. World Development 38(4): 445-454.

Ramirez, A. 2013. A Multi-Stage Almost Ideal Demand System: The Case of Beef Demand in Colombia. Revista Colombiana De Estadistica 36(1): 23-42.

Red Meat Abattoir Association. 2015. Weekly Price Report. Available by subscription.

Red Meat Levy Administration. 2015. Actual slaughter figures per province. Available at: http://www.levyadmin.co.za/levy-results-a-statistics.html

Seale, J.L., Regmi, A. and Bernstein, J. 2003. International evidence on food consumption patterns. Technical Bulletin 1904: 64-65. Economic Research Service at the United States Department of Agriculture. Available at: http://www.ers.usda.gov/media/285613/tb1904_1_.pdf

South African Audience Research Foundation (SAARF). 2004. Living Standards Measure. Available by subscription.

South African Audience Research Foundation (SAARF). 2009. Living Standards Measure. Available by subscription.

South African Audience Research Foundation (SAARF). 2013. Living Standards Measure. Available by subscription.

South African Poultry Association (SAPA). 2015. Broiler Price Report. Available at: http://www.sapoultry.co.za/home/monthly-broiler.php

South African Poultry Association (SAPA). 2015. Product Mix Report. Available at: http://www.sapoultry.co.za/home/monthly-broiler.php

StatsSA. 2015. Mid-year population estimates - Statistical release P0302; Statistics South Africa.

StatsSA. 2006. Income and Expenditure Survey. Available at www.statssa.gov.za.

StatsSA. 2011. Income and Expenditure Survey. Available at www.statssa.gov.za.

Taljaard, P. 2003. Econometric Estimation of the demand for meat in South Africa. M.Sc Thesis, University of the Free State Bloemfontein.

Taljaard, P., Jooste, A. and Asfaha, T. 2006. Towards a broader understanding of South African consumer spending on meat. Agrekon 45(2): 214-224.

Tiffin, A. and Tiffin, R. 1999. Estimates of food demand elasticities for Great Britain: 19721994. Journal of Agricultural Economics 50(1): 140-147. Available at: <Go to ISI $>: / / 000079238600010$. 
Tschirley, D., Reardon, T., Dolislager, M. and Snyder, J. 2015. The rise of a middle class in East and Southern Africa: Implications for food system transformation. Journal of International Development 27(5): 628-646.

Vermeulen, H. and Schönfeldt, H. 2015. Dynamic meat consumption behaviour of the middle class. Red Meat Producers Organisation Conference, Kimberley.

Visagie, J. 2015. Growth of the middle class: Two perspectives that matter for policy. Development Southern Africa 32(1): 3-24. 